\title{
Narzędzia public relations wykorzystywane w kreowaniu wizerunku organizacji pozarządowej
}

\section{Wstęp}

Obecność coraz większej liczby organizacji pozarządowych w ostatnich latach staje się czynnikiem wzrostu poziomu konkurowania o zasoby dostępne w społeczeństwie. Organizacje dokładają wielu starań, aby zwrócić uwagę ludności na problemy będące przedmiotem ich działalności. Istotną rolę odgrywa zatem ich wizerunek oraz umiejętność komunikowania się $\mathrm{z}$ otoczeniem.

Komunikacja społeczna, w tym działania z obszaru public relations (PR), odgrywa istotną rolę w funkcjonowaniu organizacji. Poprzez wchodzenie w interakcje wpływa się na kształtowanie określonych postaw w społeczeństwie oraz postrzeganie organizacji. Jest to proces, który odbywa się stale, ponieważ „nawet brak informacji jest przecież informacją" [Rozwadowska 2002, s. 106-107]. Z tego powodu należy zadbać o jej świadome kształtowanie oraz systematyczną kontrolę, aby uzyskać zamierzone cele.

Z kolei pozytywny wizerunek jest bardzo ważny, ponieważ pozwala na osiągnięcie przewagi konkurencyjnej nad obecnymi na rynku innymi organizacjami pozarządowymi. Taka sytuacja wpływa korzystnie na poprawę jakości relacji z otoczeniem i wzrost zaufania do organizacji.

Celem opracowania jest przedstawienie narzędzi PR wykorzystywanych przez organizacje pozarządowe $\mathrm{w}$ kontaktach $\mathrm{z}$ otoczeniem. 


\section{Podstawowe techniki i narzędzia public relations wykorzystywane w organizacji pozarządowej}

Public relations jest sposobem komunikowania organizacji $\mathrm{z}$ otoczeniem, a tym samym formą docierania do otoczenia $z$ informacją pochodząca z wiarygodnych źródeł. Konieczne jest spełnienie warunku, że przedsięwzięcia tego typu będą realizowane w sposób ciagły oraz systematyczny [Wiktor 2013, s. 238]. Kotler [2012, s. 565] w obszarze public relations wskazuje na takie działania, jak: relacje z prasą, nagłaśnianie informacji o produktach, komunikację korporacyjna, lobbing i doradztwo.

Tworzenie tożsamości przedsiębiorstwa, zarządzanie sytuacją kryzysową oraz sponsoring to główne działania, na które zwraca uwagę Budzyński [2005, s. 11]. W związku z wielością definicji i szerokim zakresem pojęcia wymienia się także wiele funkcji PR. W podstawowej klasyfikacji Wiktor [2013, s. 233-235] wyróżnia funkcje: informacyjną, perswazyjną, konkurencyjności i stałej obecności rynkowej.

Podstawą skutecznego doboru narzędzi PR jest wykorzystanie różnych kryteriów. Są nimi między innymi cel, grupa odbiorców, zasoby finansowe.

W public relations najistotniejszą i jednocześnie pierwszą grupą zainteresowania są pracownicy, a w organizacji pozarządowej również wolontariusze. $\mathrm{W}$ literaturze przedmiotu znane jest powiedzenie, że PR zaczyna się w domu. Waga komunikacji wewnętrznej jest nie do przecenienia. Poczucie lojalności i zaangażowania grup otoczenia wewnętrznego stanowi o sukcesie bądź porażce organizacji.

Iwankiewicz-Rak [2006, s. 84] precyzuje cele, dla których są podejmowane działania z zakresu wewnętrznego PR i wyszczególnia następujące:

- tworzenie poczucia wspólnoty i lojalności,

- motywowanie do pracy,

- zachęcanie do innowacyjności i przejmowania inicjatywy,

- uzyskanie aprobaty dla przyjmowanych kierunków rozwoju,

- eliminowanie skutków kryzysu w organizacji,

- tworzenie instrumentów oraz kanałów komunikacji wewnętrznej.

Budowanie organizacji spójnej wewnętrznie jest gwarancją pozytywnego oddziaływania zarówno na obecnych, jak i potencjalnych członków. Istotne jest to szczególnie w organizacjach nienastawionych na zysk. Spójność organizacyjną można osiaggnąć, stosując instrumenty wewnętrznego PR. Wśród nich można wymienić przykładowo: narady, gazetę zakładową, sprawozdania, biuletyny, szkolenia, pochwały, wyróżnienia, zebrania, dyskusje grupowe, spotkania inte- 
gracyjne, uroczystości wewnętrzne, tablice informacyjne czy znaki identyfikacji wizualnej.

Jednym z najtańszych i najskuteczniejszych narzędzi są tablice informacyjne. Służą do przekazywania informacji pracownikom i komunikowania z nimi. Podstawowym warunkiem ich skuteczności jest systematyczna ich aktualizacja, atrakcyjność wizualna, przejrzystość i uporządkowana prezentacja informacji. Aby zrealizować drugi cel ich funkcjonowania związany z komunikacją, należy zadbać o stworzenie mechanizmów umożliwiających reakcję zwrotną na zamieszczane informacje. Przykładem może być pojemnik na pomysły, uwagi, ankiety [Rozwadowska 2002, s. 125-126].

Wśród tradycyjnych instrumentów znajduje się również gazeta zakładowa, która pełni dwie funkcje: informacyjną i integracyjną. Funkcja informacyjna dotyczy prezentowania najważniejszych wydarzeń dotyczących organizacji. Zaliczane są do nich zarówno aktualnie prowadzone działania, jak i cele oraz zamierzenia dotyczące przyszłości. Gazeta może być również źródłem bardziej ogólnych informacji na przykład o sektorze organizacji pozarządowych, rynku pracy czy zmianach w przepisach prawa. Funkcja integracyjna dotyczy zespolenia społeczności poprzez dostarczanie informacji o życiu socjalnym członków organizacji. Gazeta może zawierać między innymi zdjęcia oraz relacje ze spotkań integracyjnych, informacje o nowych członkach organizacji czy zdobytych wyróżnieniach. Oprócz treści gazety ważny jest również sposób jej dystrybucji. Powinna być ona dostępna dla każdego pracownika czy wolontariusza, dlatego należy dostosować jej format do warunków ich pracy. Osobom mającym stały dostęp do Internetu może być wysyłana w formie newslettera. Jest to zdecydowanie tańsze rozwiązanie. Gdy ktoś nie ma dostępu do urządzeń elektronicznych, należy dostarczać mu ją w formie papierowej. Ważną cechą tego narzędzia jest jego cykliczność, która z jednej strony zapewnia aktualność treści, a z drugiej staje się czynnikiem budowania lojalnej grupy czytelników ${ }^{1}$.

Uroczystości wewnętrzne mogą mieć charakter zarówno oficjalnych wydarzeń, jak i mniej formalnych spotkań, mogą trwać kilka minut lub nawet cały dzień. Ich forma zależy przede wszystkim od wielkości organizacji oraz powodu, dla którego są organizowane. Głównym celem spotkań integracyjnych jest lepsze poznanie się członków organizacji oraz budowanie odpowiedniej atmosfery i poczucia wspólnoty.

Szkolenia, oprócz podstawowej funkcji, jaką jest zdobycie określonych umiejętności, odgrywają rolę informacyjną (poprzez prezentację organizacji, jej celów, misji i wyznawanych wartości) oraz integracyjną. Dają one możliwość

\footnotetext{
${ }^{1}$ http://www.proto.pl/PR/Pdf/art_Zelazko.pdf.
} 


\section{4}

nawiązania kontaktu wolontariuszy z pracownikami, zwiększają również wydajność pracy i zaangażowanie w nią pracowników [Rozwadowska 2002, s. 131].

Otoczenie zewnętrzne organizacji pozarządowej tworzą osoby korzystające ze świadczonych przez nią usług (klienci), wspomagający działania (fundatorzy) oraz społeczeństwo. Do tych grup podmiotów adresowane są działania zewnętrznego PR, którego głównym celem jest zachęcenie podmiotów spoza organizacji do podjęcia współpracy lub jej kontynuacji i budowanie zaufania, do czego niezbędne są odpowiedni wizerunek organizacji oraz jej reputacja.

Według Wójcika [2009, s. 817-818], celem działań PR w perspektywie środowisk społeczno-politycznych i branżowych powinno być:

- tworzenie pozytywnego wizerunku organizacji,

- pozyskiwanie poparcia dla działań, polityki,

- uzyskiwanie przejrzystości spraw organizacji oraz specyficznego wyprofilowania zasad działania,

- aktywizacja.

Narzędzia PR stosowane do realizacji wymienionych celów obejmują między innymi wysłuchiwanie opinii, ogłaszanie stanowisk, sprawozdań, propozycji współpracy, rozmowy bezpośrednie i telefoniczne, dni otwarte, listy indywidualne informacyjne oraz zwracające się o poparcie, a także imprezy i wydarzenia.

Liczniejsze i rozproszone grupy otoczenia są powodem, dla którego należy w większym stopniu wykorzystywać komunikację medialną, czyli ogłoszenia i komunikaty prasowe, artykuły, a także własne media, ulotki, plakaty oraz informacje zamieszczone $\mathrm{w}$ Internecie, a także pozostałe media elektroniczne w kampaniach społecznych. Media są jedną z grup otoczenia, którą także za pośrednictwem PR należy zainteresować celami organizacji, zwrócić uwagę na jej potrzeby i problemy, tak dalece, aby same zaczęły komunikować szerokiej publiczność misję organizacji i kreować jej wizerunek.

\section{Wybrane narzędzia public relations wykorzystywane przez Polską Akcję Humanitarną}

Od 2004 roku Polska Akcja Humanitarna (PAH) ma status organizacji pożytku publicznego. Misją tej fundacji jest „uczynić świat lepszym przez zmniejszenie cierpienia i promowanie wartości humanitarnych" [PAH 2014]. Celem statutowym jest ,organizowanie i niesienie pomocy humanitarnej i rozwojowej, dobroczynnej i charytatywnej, społecznie użytecznej i oświatowej oraz przeciwdziałanie wykluczeniu społecznemu" [Statut Fundacji...].

Polska Akcja Humanitarna działa w pięciu obszarach: głód i niedożywienie, woda i sanitariaty, pomoc uchodźcom, repatriantom i migrantom, pomoc 
humanitarna, dostęp do edukacji. W ramach walki z głodem i niedożywieniem prowadzony jest od 1998 roku program „Pajacyk”, którego głównym zadaniem jest finansowanie posiłków w szkołach i placówkach środowiskowych oraz zapewnienie dostępu do żywności w regionach świata, gdzie panuje ubóstwo lub toczą się wojny oraz konflikty zbrojne. Do 2014 roku z tej pomocy skorzystały ponad 62 tysiące dzieci w polskich szkołach. Ponadto w Sudanie Południowym oraz Somalii wybudowano klinikę dożywiającą dzieci i matki w stanie wygłodzenia $^{2}$.

Szczególnie trudna sytuacja żywnościowa w Sudanie Południowym wymaga interwencji organizacji humanitarnych. W lutym 2017 roku UNICEF (Fundusz Narodów Zjednoczony na rzecz Dzieci), WFP (Światowy Program Żywnościowy) i FAO (Organizacja Narodów Zjednoczonych do spraw Wyżywienia i Rolnictwa) ogłosiły stan klęski głodu w niektórych regionach kraju, gdzie z powodu niedożywienia cierpi 100 tysięcy osób, a kolejny milion jest zagrożony niedożywieniem. Obecna interwencja PAH w regionie obejmuje ponad 30 tysięcy osób, w tym 3750 osobom udzielona jest bezpośrednia pomoc w zakresie dostępu do żywności, aby zapobiec eskalacji klęski głodu ${ }^{3}$.

Od 2004 roku jest prowadzona także „Kampania Wodna”. Jej główny cel to zwrócenie uwagi na kwestię niedoboru wody pitnej na świecie i zaangażowanie Polaków w pomoc ludziom, którzy nie mają możliwości korzystania z bezpiecznych źródeł wody. Uzyskiwane dzięki temu programowi środki finansowe umożliwiają tworzenie miejsc z dostępem do wody pitnej - studni, stacji uzdatniania wody, sieci kanalizacyjnych ${ }^{4}$.

W celu pomocy uchodźcom, repatriantom i migrantom realizowany jest między innymi program „Dobry start w zasięgu ręki!”, w ramach którego oferowana jest pomoc imigrantom polskiego pochodzenia oraz cudzoziemcom przybywającym ze Wschodu w adaptacji i integracji z polskim społeczeństwem. Program realizowany jest poprzez organizowanie szkoleń dotyczących wiedzy i umiejętności pożądanych na rynku pracy, zajęć językowych, kursów zawodowych, spotkań integracyjnych oraz zapewnienie pomocy prawnej i psychologicznej ${ }^{5}$.

$\mathrm{W}$ ramach pomocy humanitarnej podejmowane są działania kierowane do ludności cywilnej, która znajduje się w trudnej sytuacji życiowej, będącej skutkiem kataklizmów naturalnych lub konfliktów zbrojnych. W pierwszej kolejności zapewnia się pomoc medyczną oraz dostarcza żywność, wodę i schronienie,

\footnotetext{
${ }^{2} \mathrm{PAH}$, http://www.pajacyk.pl/\#dzialania (dostęp: 19.11.2015).

3 PAH, (http://www.pah.org.pl/nasze-dzialania/218/5581/glod_w_sudanie_poludniowym_i_somalii_apelujemy_o_pomoc (dostęp: 22.06.2017).

${ }^{4} \mathrm{PAH}$, http://www.pah.org.pl/nasze-dzialania/178/kampania_wodna (dostęp: 19.11.2015).

${ }^{5} \mathrm{PAH}$, http://www.pah.org.pl/nasze-dzialania/529/dobry_start (dostęp: 19.11.2015).
} 


\section{6}

a następnie działania skoncentrowane są na przywróceniu do użytkowania najważniejszych elementów infrastruktury.

Polska Akcja Humanitarna realizuje projekty, poprzez które stara się zapewnić ludziom mieszkającym w najbiedniejszych bądź zniszczonych wojną lub klęskami żywiołowymi rejonach świata dostęp do edukacji. Swoją działalnością obejmuje również przebywające w Polsce dzieci uchodźców, umożliwiając im naukę języka polskiego. Wymienione przykłady programów i realizowanych w tym obszarze kampanii społecznych wpisują się niewątpliwie w szeroko rozumianą komunikację organizacji z otoczeniem.

Wśród wielu narzędzi PR wykorzystywanych w ramach komunikacji z wewnętrznymi grupami otoczenia jednym z bardziej rozpowszechnionych są znaki identyfikacji wizualnej. Jednym z podstawowych elementów tego systemu jest logo, między innymi na: wizytówkach, drukach firmowych, materiałach reklamowych, strojach, naklejkach czy identyfikatorach. Oznakowane są nim tablice informacyjne znajdujące się na fasadach budynków. Jest ono eksponowane również na stronie internetowej organizacji.

Ważnym narzędziem wykorzystywanym przez PAH są szkolenia. Organizacja zapewnia je swoim pracownikom oraz wolontariuszom zgodnie z zakresem obowiązków określonych przepisami wewnętrznymi i statutem.

Narzędzia wewnętrznego public relations stosowane są również w odniesieniu do osób indywidualnych oraz przedsiębiorstw będących członkami Klubu PAH SOS. Podmioty te otrzymują między innymi: legitymacje członkowskie, biuletyny informacyjne o działalności fundacji czy gadżety ${ }^{6}$.

Nie można zapomnieć o kontaktach zewnętrznych. Polska Akcja Humanitarna w ramach zewnętrznego PR organizuje wiele wydarzeń. Należą do nich przykładowo marsze po wodę z okazji obchodów światowego dnia wody. Ich celem jest zwrócenie uwagi na problem braku powszechnego dostępu do wody pitnej w niektórych rejonach świata oraz aktywizowanie społeczeństwa do wsparcia fundacji.

Ważnym aspektem funkcjonowania organizacji pozarządowej jest pozyskiwanie środków na swoją działalność. W trosce o transparentność prowadzonej działalności fundacja umieszcza na swojej stronie internetowej sprawozdania merytoryczne oraz finansowe, aby darczyńcy mieli pewność, że przeznaczone środki są wydatkowane w odpowiedni sposób.

Kolejnym narzędziem wykorzystywanym przez PAH jest korespondencja indywidualna wysyłana do podmiotów angażujących się w jej działalność, w tym podziękowania. Nieodłącznym elementem form drukowanych jest logo fundacji, całość jest zachowana w biało-niebieskiej kolorystyce. Fundacja przy-

\footnotetext{
${ }^{6} \mathrm{PAH}, \mathrm{http}: / /$ www.pah.org.pl/klub (dostęp: 05.06.2015).
} 
gotowuje również materiały w formie własnych wydawnictw. Są to krótkie analizy, raporty, jak również dłuższe publikacje. Materiały są dostępne w formie elektronicznej na stronie internetowej organizacji oraz w tradycyjnej formie papierowej, którą można nabyć bezpłatnie ${ }^{7}$.

W celu nawiązania współpracy z mediami przygotowywane są informacje prasowe dotyczące bieżących wydarzeń oraz akcji. Są one następnie umieszczane na stronie internetowej, w miejscu przeznaczonym dla mediów.

Wszystkie działania PR są przygotowywane oraz koordynowane przez członków zespołu do spraw komunikacji.

\section{Metodologia badań}

Celem opracowania jest przedstawienie narzędzi PR wykorzystywanych przez organizacje pozarządowe w kontaktach z otoczeniem. W czerwcu 2015 roku przeprowadzono badanie ankietowe, aby zdefiniować skuteczność instrumentarium PR stosowanego przez organizacje pozarządowe i znajomość wizerunku wybranej organizacji pozarządowej, tj. Polskiej Akcji Humanitarnej.

Kwestionariusz ankiety zawierał pytania dotyczące opinii respondentów na temat wpływu narzędzi PR na wizerunek organizacji pozarządowych oraz oceny wiarygodności przekazów medialnych dotyczących tych organizacji. Pytania dotyczące wizerunku PAH skierowane były jedynie do osób, które zadeklarowały jej znajomość (97 osób). Pytania miały charakter zamknięty. Wyniki badania zostały zaprezentowane $\mathrm{w}$ formie opisowej oraz graficznej.

W przeprowadzonym badaniu udział wzięło 141 osób, wśród których $58,6 \%$ stanowiły kobiety. Najwięcej było osób w przedziale wiekowym 18-25 lat $(54,3 \%)$. Co piaty badany był reprezentantem grupy wiekowej 26-35 lat, a najmniej było osób w wieku powyżej 50 lat $(8,6 \%)$. Ponad połowę stanowiły osoby, które ukończyły szkołę wyższą (55,7\%). Posiadanie wykształcenia średniego zadeklarowało $32,9 \%$, a podstawowego $8,6 \%$ respondentów. Najmniej liczną grupę stanowiły osoby z wykształceniem zawodowym (2,9\%). Respondenci pochodzili głównie z miast powyżej 500 tysięcy mieszkańców $(61,4 \%)$. Licznie reprezentowani byli także mieszkańcy wsi, przynależność do tej kategorii zadeklarowało $28,6 \%$ respondentów.

\footnotetext{
${ }^{7}$ PAH, http://www.pah.org.pl/nasze-dzialania/40/295/wydawnictwo_pah (dostęp: 05.06.2015).
} 


\section{Wyniki i wnioski z badań własnych}

Celem przeprowadzonego badania ankietowego było między innymi poznanie opinii na temat narzędzi PR wykorzystywanych przez organizacje pozarządowe. Narzędzia te zostały podzielone według grup odbiorców. W pierwszej kolejności ankietowani zostali poproszeni o określenie w pięciostopniowej skali Likerta znaczenia poszczególnych narzędzi PR stosowanych wobec środowiska wewnętrznego (wolontariuszy, pracowników) w procesie kreowania wizerunku. Według respondentów, największe znaczenie miały rozmowy bezpośrednie $(4,1)$ i szkolenia $(4,0)$, a najmniejsze uroczystości wewnętrzne $(2,7)$, formy drukowa-

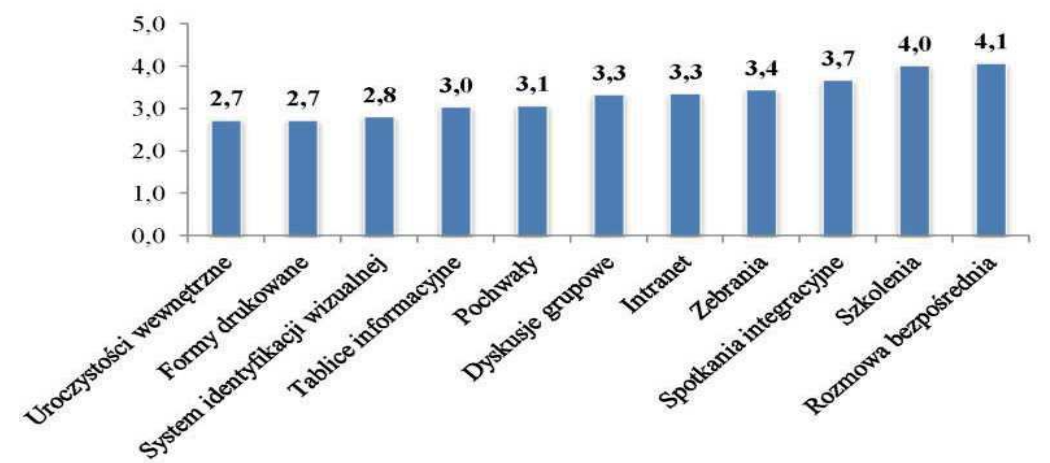

\section{Rysunek 1}

Ranking narzędzi wewnętrznego public relations stosowanych w kreowaniu wizerunku organizacji pozarządowej

Źródło: Badania własne.

ne $(2,7)$ i system identyfikacji wizualnej $(2,8)$. Szczegółowy ranking ocen przedstawiono na rysunku 1.

Zapytano również o narzędzia PR wykorzystywane wobec grup otoczenia zewnętrznego (fundatorzy, opinia publiczna). Według opinii badanych, największe znaczenie miała strona internetowa $(4,3)$ oraz organizowane wydarzenia $(3,9)$. Mniej istotne ich zdaniem były telefoniczne linie informacyjne $(2,6)$, listy indywidualne $(2,8)$ oraz konferencje prasowe $(2,9)$. Szczegółowe dane przedstawiono na rysunku 2.

Respondenci zostali także poproszeni o ocenę relacji organizacji z mediami. W związku z tym zapytano, czy zgadzają się z twierdzeniem, że „Informacje o działalności organizacji pozarządowych często pojawiają się w mediach” i czy „Przekazy medialne są bardziej wiarygodne od innych kanałów komunikowania”. Niemal połowa respondentów nie zgodziła się z tym, że informacje o funkcjonowaniu organizacji pozarządowych pojawiają się często w mediach $(48,5 \%)$, a tylko $14,5 \%$ badanych potwierdziło tę opinię. Około $37 \%$ respondentów nie po- 


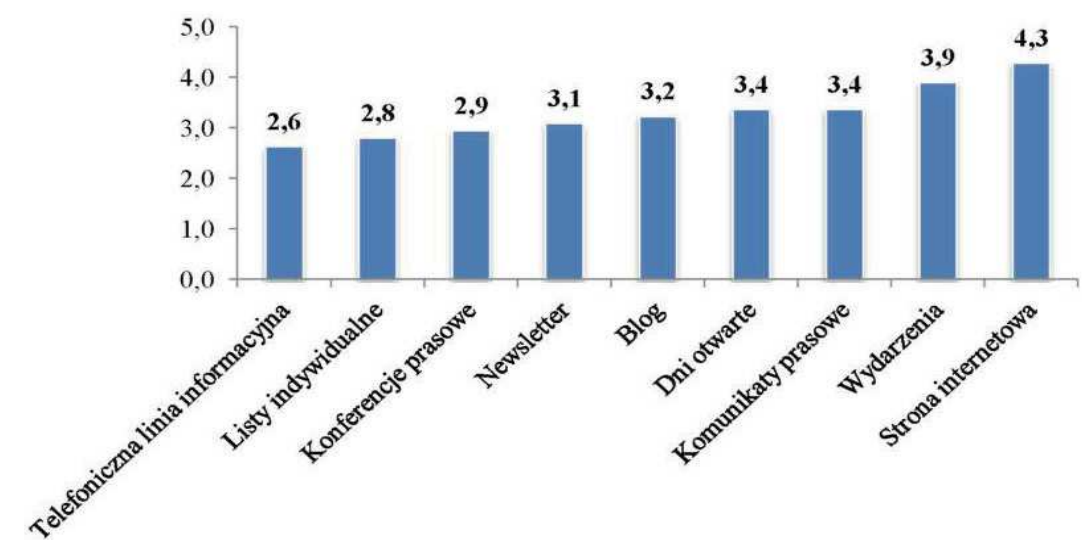

\section{Rysunek 2}

Ranking narzędzi zewnętrznego public relations stosowanych w kreowaniu wizerunku organizacji pozarządowej

Źródło: Badania własne.

trafiło zająć jednoznacznego stanowiska. Ankietowani w większości negatywnie ocenili także wiarygodność przekazów medialnych $(54,3 \%)$. Co piąty uczestnik badania uznał, że medialny kanał komunikowania jest bardziej wiarygodny niż inne, przy $25 \%$ udziale niezdecydowanych.

Kolejna część badania dotyczyła poznania opinii na temat wizerunku PAH. W pierwszej kolejności ankietowani zostali zapytani o znajomość tej organizacji. Niemal $69 \%$ znała organizację, w tym 9\% respondentów zadeklarowało angażowanie się w jej działalność. Spośród osób znających PAH niewiele ponad połowa $(52,1 \%)$ uważała, że jest to powszechnie znana i rozpoznawalna organizacja pozarządowa. Zdecydowana większość $(95,8 \%)$ poprawnie wskazała także logo PAH spośród trzech znaków przedstawionych do wyboru. Ankietowani zadeklarowali, że najczęściej informacje na temat PAH pozyskują z telewizji, w drugiej kolejności z Internetu. Szczegółowe dane przedstawiono na rysunku 3.

Zapytano również ankietowanych o dziedziny, z którymi łączą funkcjonowanie PAH. Najczęściej formułowaną odpowiedzią było niesienie pomocy $(79,2 \%)$, a w drugiej i trzeciej kolejności kojarzono organizację $\mathrm{z}$ humanitaryzmem oraz wolontariatem, na co wskazało odpowiednio 66,7 i 58,3\% respondentów (rys. 4).

Podczas badania zweryfikowano także stopień znajomość kampanii prowadzonych przez PAH (rys. 5). Respondentom przedstawiono przykłady kampanii prowadzonych przez organizacje pozarządowe, spośród których mieli wybrać te prowadzone przez PAH. Połowa osób wskazała na „Kampanię Wodną”, niewiele mniej $(45,8 \%)$ na akcję „Pajacyk” oraz „SOS Syria”. Mniej rozpoznawalną i utożsamianą z fundacją jest „Szkoła humanitarna” (29,2\%). Szczegółowe dane przedstawiono na rysunku 5. 
90

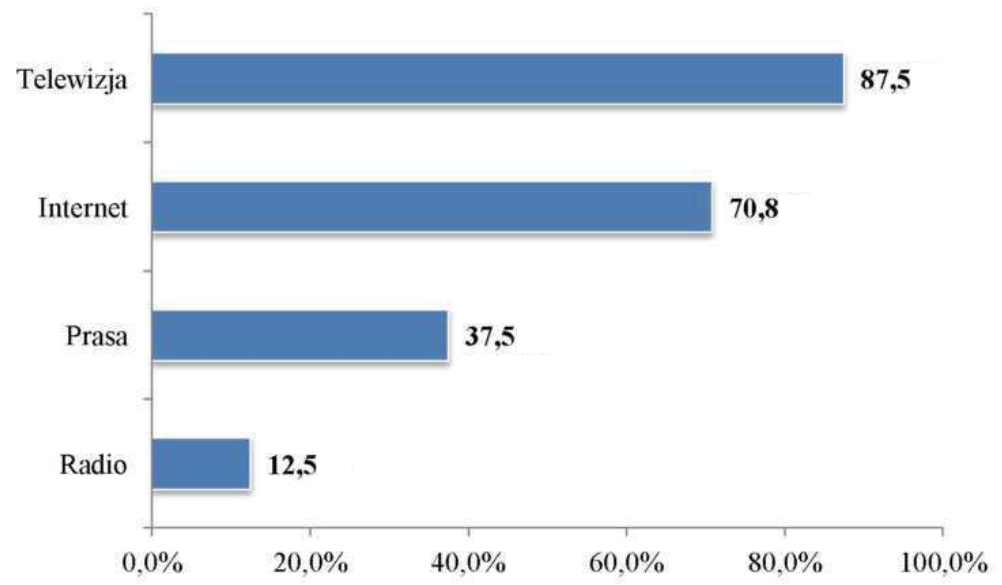

Badany mógł wskazać więcej niż jedną odpowiedź.

\section{Rysunek 3}

Medialne źródła informacji na temat Polskiej Akcji Humanitarnej Źródło: Badania własne.

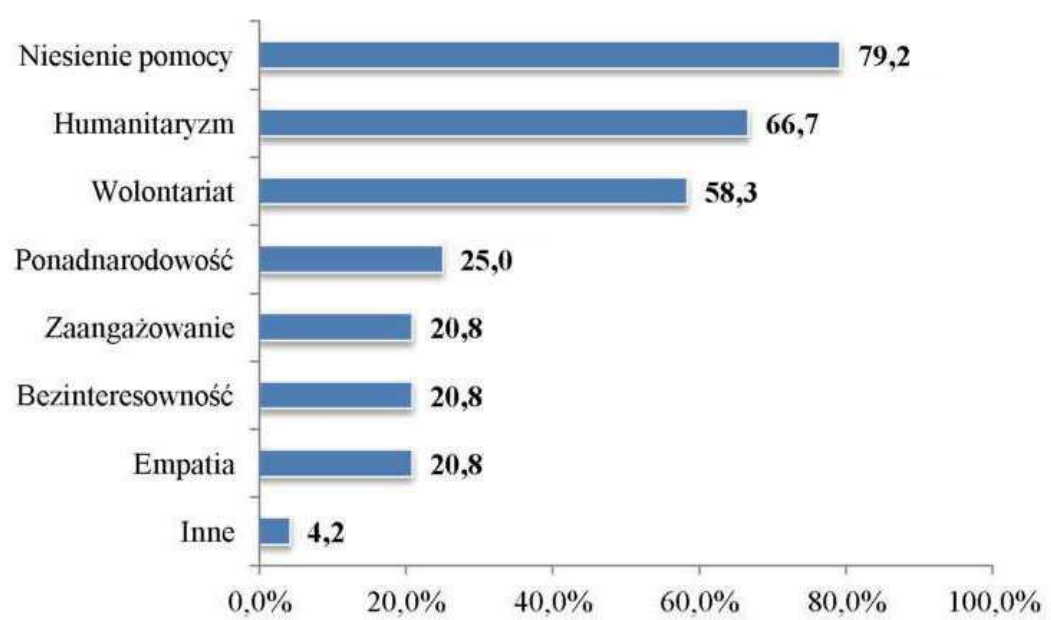

Badany mógł wskazać więcej niż jedna odpowiedź.

\section{Rysunek 4}

Skojarzenia respondentów związane z Polską Akcją Humanitarną Źródło: Badania własne. 


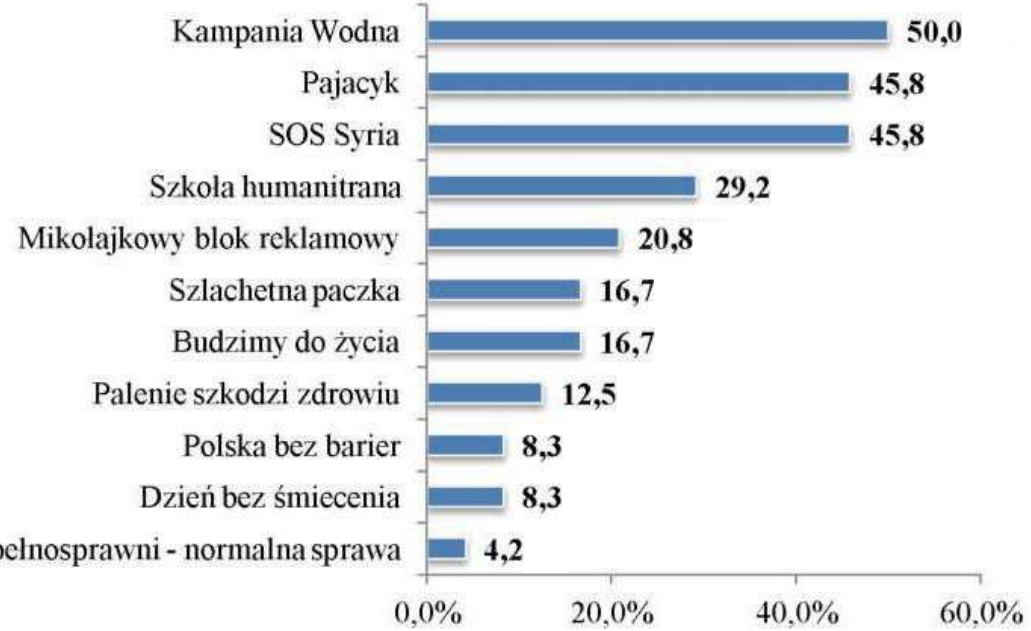

Rysunek 5

Znajomość kampanii prowadzonych przez Polską Akcję Humanitarną wśród badanych Źródło: Badania własne.

\section{Podsumowanie}

Właściwy dobór narzędzi public relations jest bardzo ważny w procesie kształtowania wizerunku organizacji pozarządowej. Zgodnie z definicją, powinny to być działania planowe i długofalowe, a ich skuteczność zależy w dużym stopniu od uwzględnienia preferencji otoczenia oraz stworzenia odpowiedniej strategii.

Jak wynika z badania ankietowego, dla większości respondentów PAH jest znaną organizacją. Najczęściej kojarzona jest ona z pomocą humanitarną, co może wynikać bezpośrednio z jej nazwy. Aktualności na jej temat respondenci poznali głównie przez przekaz z Internetu, choć równocześnie nisko ocenili wiarygodność wymienionych mediów. Można przypuszczać, że wynika to z charakteru tego rodzaju komunikacji, czyli braku informacji zwrotnej w przypadku mediów tradycyjnych, tak istotnej w komunikacji organizacji pozarządowej $\mathrm{z}$ otoczeniem.

Zdecydowana większość badanych $(95,8 \%)$ potrafiła wskazać logo organizacji. Mniej rozpoznawalne były dla nich kampanie społeczne fundacji, takie jak „Kampania Wodna”, „Pajacyk” , „SOS Syria”, i to wśród osób, które zadeklarowały znajomość organizacji. Uprawnione zatem jest stwierdzenie, że dobrze byłoby zintensyfikować szeroko rozumiane działania komunikacyjne, aby zwiększyć stopień rozpoznawalności organizacji i identyfikacji prowadzonych aktywności. 
W organizacjach pozarządowych istotnym elementem budowania wizerunku są sami pracownicy i wolontariusze. Respondenci uznali rozmowy bezpośrednie za najważniejszy element wewnętrznego PR. Można przypuszczać, że osoby związane z organizacjami pozarządowymi oczekują właśnie takiego rodzaju komunikacji. Wśród narzędzi zewnętrznego PR zwrócono uwagę na stronę internetową i organizowane wydarzenia. Współcześnie strona internetowa stanowi źródło wielu informacji dla osób niebędących bezpośrednio zaangażowanych w działalność danej organizacji. Jest ona również jej wizytówką, dlatego odgrywa tak ważną rolę w kreowaniu wizerunku. Uczestnictwo w wydarzeniach pozwala natomiast skonfrontować informacje przekazywane za pomocą Internetu z rzeczywistością, co wpływa na budowanie zaufania do organizacji i jej wiarygodności.

\section{Literatura}

BUDZYŃSKI W., 2005: Public relations: zarzqdzanie reputacja firmy, Poltext, Warszawa. IWANKIEWICZ-RAK B., 2006: Public relations $w$ instytucjach publicznych i organizacjach pozarzadowych, [w:] J. Olędzki (red.), Public relations. Znaczenie spoleczne i kierunki rozwoju, Wydawnictwo Naukowe PWN, Warszawa, 81-105.

KOTLER Ph., KELLER K.L., 2012: Marketing, Rebis, Poznań.

Polska Akcja Humanitarna (PAH), 2014: Raport za rok 2013, Warszawa, http://www.pah.org. $\mathrm{pl} / \mathrm{rn} / 4414 / \mathrm{PAH} \% 20$ raport\%20roczny\%202013pl\%20LR\%20strony (dostęp: 19.11.2015).

ROZWADOWSKA B., 2002: Public relations - teoria, praktyka, perspektywy, Studio Emka, Warszawa.

Statut Fundacji Polska Akcja Humanitarna, http:// pah.org.pl.

WIKTOR J.W., 2013: Komunikacja marketingowa, Wydawnictwo Naukowe PWN, Warszawa.

WOJCIK K., 2009: Public relations. Wiarygodny dialog z otoczeniem, Wolters Kluwer, Warszawa.

\section{Abstrakt}

Komunikacja społeczna, w tym działania z obszaru public relations (PR), odgrywa istotną rolę w funkcjonowaniu każdej organizacji, także pozarządowej. Poprzez wchodzenie w interakcje wpływa się na kształtowanie określonych postaw w społeczeństwie oraz postrzeganie organizacji. Celem opracowania jest przedstawienie narzędzi PR wykorzystywanych przez organizacje pozarządowe w kontaktach z otoczeniem. W czerwcu 2015 roku przeprowadzono badanie ankietowe (141 osób), aby zdefiniować instrumentarium PR stosowane przez organizacje pozarządowe i określić znajomość wizerunku wybranej organizacji po- 
zarządowej, tj. Polskiej Akcji Humanitarnej (PAH). W artykule zaprezentowano narzędzia PR wykorzystywane przez PAH w procesie kreowania wizerunku.

Specyfika organizacji pozarządowej determinuje wybór narzędzi kreacji wizerunku. Spośród wielu dostępnych instrumentów, zarówno w kategorii tradycyjnych, jak i nowoczesnych, najistotniejszymi z perspektywy kształtowania wizerunku wewnętrznego były rozmowy bezpośrednie i szkolenia. Dla budowania zewnętrznego wizerunku największe znaczenie miała strona internetowa oraz organizowane wydarzenia.

Słowa kluczowe: organizacja pozarządowa, public relations, Polska Akcja Humanitarna, wizerunek

\title{
Public relations instruments in creating an image of the non-governmental organizations
}

\begin{abstract}
Social communication, including activities in the area of public relations (PR), plays an important role in the functioning of any organization, including non-governmental one. By interacting, it influences the development of certain attitudes in society and the perception of the organization. The aim of the study is to present PR tools used by the non-governmental organizations in dealing with the environment for building the image. In June 2015 a survey was carried out (141 people) to define the effectiveness of PR instruments used by the nongovernmental organizations and knowledge of the image of the selected non-governmental organization, i.e. the Polish Humanitarian Organization (PHO). The article presents the PR tools used by the PHO in the process of creating an image. The specificity of the non-governmental organizations determines the choice of image creation tools. Out of many available instruments, both in traditional and modern terms, personal interviews and training were the most important in terms of shaping the image. For building the external image the most important were website and organized events.
\end{abstract}

Key words: non-governmental organizations, public relations, Polish Humanitarian Organization, image 